\title{
Detection of DGAT1 gene polymorphism and its effect on selected biochemical indicators in dairy cows after calving
}

\author{
Lenka Lešková1, Miroslav Bauer, ${ }^{2,3}$, Peter Chrenek ${ }^{2,4}$, Zuzana Lacková1,

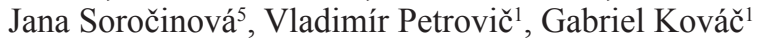 \\ ${ }^{1}$ University of Veterinary Medicine and Pharmacy, Clinic for Ruminants, Košice, Slovak Republic \\ ${ }^{2}$ Animal Production Research Centre, Nitra, Slovak Republic \\ ${ }^{3}$ Constantine the Philosopher University, Nitra, Slovak Republic \\ ${ }^{4}$ Slovak University of Agriculture in Nitra, Nitra, Slovak Republic \\ ${ }^{5}$ University of Veterinary Medicine and Pharmacy, Clinic for Swine, Košice, Slovak Republic
}

Received April 25, 2012

Accepted May 29, 2013

\begin{abstract}
The aim of the study was to detect DGAT1 K232A polymorphism in 57 dairy cows of the Slovak Spotted breed and its crossbreds, and to assess possible effect of the given polymorphism on selected metabolic indices in blood serum after calving. Using the PCRRFLP method with improved primers enabling better differentiation of genotypes we identified 45 homozygotes for alanine variant in this locus ( $A A$ genotype), 2 homozygotes for lysine variant ( $K K$ genotype), and 10 heterozygotes ( $A K$ genotype). Genotype frequencies were 0.790 for $A A$ genotype, 0.175 for $A K$ genotype, and only 0.035 for $K K$ genotype. Allele frequencies were counted as 0.877 for $A$ allele and 0.123 for $K$ allele. In both groups of animals ( $A A$ and $A K$ genotype) increased mean values above the upper reference limit of lactate dehydrogenase, and total bilirubin, and decreased levels below the lower reference limit of triglycerides were detected. In the group of animals with $A A$ genotype we also noticed decreased levels of non-esterified fatty acids. On the other hand, increased serum concentrations of total immunoglobulins were found in animals with $A K$ and $K K$ genotype. This is the first study concerning DGAT1 polymorphism in the Slovak Spotted breed and its association with selected biochemical indicators.
\end{abstract}

\section{Blood chemistry, cattle, metabolism, postpartal}

Lo or et al. (2006) examined temporal gene expression in the liver of Holstein cows, and identified 85 genes with expression patterns that were affected by the level of energy intake prepartum over time. One of the genes with affected expression due to the changes in energy balance should be acyl-CoA: diacylglycerol acyltransferase-1 (DGAT1) gene. According to Kaupe et al. (2004), the DGAT1 gene has been named as a potential candidate gene, with a non-conservative substitution of lysine by alanine amino acid change $(K 232 A)$ in exon 8 producing a major effect on milk composition and yield. The $K$ allele was associated with reduced milk yield and protein yield but greater milk fat yield, milk fat concentration and milk protein concentration (Berry et al. 2010). Because of polymorphism, the DGAT1 gene has two major genetic variants ( $K$ and $A$ ); the allele $(K)$ encoding the lysine variant proved to be more efficient with regard to the milk fat synthesis, and is obviously a useful marker for milk fat traits by which bull can be evaluated and selected for future breeding programmes (Patel et al. 2009). This gene has been localized on BTA14 (Boichard et al. 2003), and encodes enzyme acyl-CoA: diacylglycerol acyltransferase (EC 2.3.1.20) that catalyses last step in triacylglycerides (TAG's) synthesis. Oikonomou et al. (2008) stated that this enzyme together with growth hormone receptor (GHR) may significantly influence selected energy metabolism traits and blood indices together with some

Address for correspondence:

MVDr. Lenka Lešková

Clinic for Ruminants, University of Veterinary

Medicine and Pharmacy in Košice

Phone: +421902416598

Komenského 73, 04181 Košice, Slovakia 
reproduction properties in dairy cows. Ashwell et al. (2004) also described possible pleiotropic effects of this polymorphism on reproduction. Moreover, identification of the individuals with optimal genotypes could beneficially affect the reproductive performance of cows (Szatkowska et al. 2011).

Excessive TAG accumulation in the liver and oxidative stress increase the risk of periparturient health disorders by predisposing the cow to fatty liver and ketosis. Fatty acids can also increase systemic inflammatory responses and are considered as positive risk factors for many pro-inflammatory periparturient diseases, even though the mechanisms of this effect are still unclear (Sordillo et al. 2009).

The aim of the study was to examine the possible effect of DGAT1 gene polymorphism on selected metabolic indices in blood serum of dairy cows after calving that have been important in assessment of negative energy balance, and may have a negative impact on the subsequent risk of metabolic and reproduction disorders.

\section{Materials and Methods}

A total of 57 dairy cows of Slovak Spotted breed and its crossbreds in the early postpartal period (5-14 days post partum) were used for the study. Animals used in the study reached the average production age of 2.5 lactations. In total $33.5 \%(\mathrm{n}=19)$ of the selected cows were primiparous, $44.7 \%(\mathrm{n}=25)$ were after second or third gravidity, and the remaining cows $(n=13)$ were older than 5 years. The average milk yield on the farm was 6.724 litres per cow per 305 days of lactation with the mean fat content of $4.1 \%$ and the average protein content of $3.452 \%$. Somatic cell count reached 190 000-320 000 during the whole year. Animals on the farm were kept in cow-sheds using the free-stabling system and had free access to the external cattleruns. Cows were fed with total mixed ratio (TMR) system using conserved plants during whole year, and ad libitum water. Composition of the feed ration is described in Table 1.

Table 1. Feed ration used for dairy cows

\begin{tabular}{lc}
\hline Components & $\mathrm{kg} / \mathrm{cow} / \mathrm{day}$ \\
\hline Alfalfa haylage & 13 \\
Corn silage & 25 \\
Lime flour & 0.20 \\
Mineral flour & 0.30 \\
High moisture maize cobs in Sil-all packs & 8 \\
Brewer's grain & 7 \\
French bean groats & 2 \\
Optigen-protected urea & 0.04 \\
\hline
\end{tabular}

Blood samples were taken by puncture of jugular vein in the morning approximately 3 $\mathrm{h}$ after feeding. Blood serum for biochemical analyses was obtained after centrifugation of clotted blood. Concentrations of glucose, total cholesterol (TCH), triacylglycerides (TAGs), $\quad \beta$-hydroxybutyrate (BHB), and serum activity of lactate dehydrogenase (LDH) were determined by means of automatic analyser Alizé (Lisabio, France) using commercial diagnostic kits (Randox Laboratories, UK). Serum concentrations of total immunoglobulins (TIg), non-esterified fatty acids (NEFA), total bilirubin (TBi), and total lipids (TL) were analysed by spectrophotometric method.

Whole blood for DNA extraction was conserved with EDTA and stored at $-80{ }^{\circ} \mathrm{C}$ until analysed. DNA was isolated by commercial QIAamp DNA Blood Mini Kit (Qiagen, Germany). Genomic DNA was genotyped by a PCR-RFLP assay for the locus responsible for the DGAT1 K232A substitution. Briefly, PCR reactions were performed in a total volume of $20 \mu \mathrm{l}$ using 10-50 ng genomic DNA as template, PCR buffer, $2.5 \mathrm{mmol} \cdot \mathrm{l}^{-1} \mathrm{MgCl}, 0.2 \mathrm{mmol} \cdot \mathrm{l}^{-1}$ of each dNTP, 5\% dimethyl sulphoxide (DMSO), 0.8 U AmpliTaq Gold DNA polymerase (Applied Biosystems, USA) and $0.4 \mu \mathrm{mol} \cdot \mathrm{l}^{-1}$ of each primer. The PCR included an initial denaturation at $95{ }^{\circ} \mathrm{C}$ for $5 \mathrm{~min}, 35 \mathrm{cycles}$ of $94{ }^{\circ} \mathrm{C}$ for $1 \mathrm{~min}, 63{ }^{\circ} \mathrm{C}$ for $1 \mathrm{~min}$ and a final extension at $72{ }^{\circ} \mathrm{C}$ for $10 \mathrm{~min}$. Modified primers for the amplification of $352 \mathrm{bp}$ fragment of bovine DGAT1 gene (sequence acc. No. AY065621.1; DGAT1 forward: 5' -catcctcttcctcaagctgttct-3'; DGAT1 reverse: 5' -gggcgaagaggaagtagtagaga-3') were designed using a Primer3 software (http://frodo.wi.mit.edu/ primer3/input.htm). Restriction endonuclease CfrI (Fermentas, Germany) was used to digest a 352 bp PCR product. The uncut fragment represents the lysine variant, whereas the $C f r I$ fragments of 199 and 153 bp represent the alanine variant. To separate the digestion products, electrophoresis on $2 \%$ agarose gel was used and DNA was visualised by GelRed dye (Biotium, USA).

Animals were divided into three groups ( $A A, A K$, and $K K$ genotype) according to the results of genotyping in DGAT1 K232A locus. All biochemical indices are presented as mean \pm SD. Results were evaluated by one-way analysis of variance (Tukey's test) with the GraphPad Prism 5 statistical software. The level of significance was set at $P<0.05$. Allele and genotype frequencies and deviation from Hardy-Weinberg equilibrium were assessed by BioToolKit software using $\chi^{2}$ test. 


\section{Results}

After genotyping of 57 samples for DGAT1 K232A polymorphism we detected three genotypes (Plate VII, Fig. 1, Table 2). Most of the animals showed to be homozygotes for $A A$ genotype (frequency 0.790 ). On the other side, only 2 were homozygotes for $K K$

Table 2. Genotypic and allelic frequencies in the DGAT1 gene locus in dairy cows

\begin{tabular}{lcc}
\hline Genotype & Number of animals & Genotype frequency \\
\hline AA & 45 & 0.790 \\
AK & 10 & 0.175 \\
KK & 2 & 0.035 \\
Total & 57 & \\
Allele & & Allele frequency \\
A & & 0.877 \\
K & & 0.123 \\
\hline
\end{tabular}

genotype in DGAT1 $K 232 A$ locus (frequency 0.035 ). The rest of them were $A K$ heterozygotes (frequency $0.175)$. Allele frequency for $A$ and $K$ alleles were 0.877 and 0.123 , respectively. Using $\chi^{2}$ test $\left(\chi^{2}=1.9659\right.$, $P=0.160882)$ we found no significant deviation from Hardy-Weinberg equilibrium in DGAT1 $K 232 A$ locus in our population of genotyped animals. We assume that much higher frequency of allele A and genotypes AA, (AK) was most probably caused by artificial selection of dairy cows for milk production, which negatively influenced the occurrence and persistence of $K$ allele. Mean production indicators are described in Table 3 . Variations among the groups with different genotypes were not significant $(P>0.05)$.

Table 3. Mean production properties according to the genotype of cows

\begin{tabular}{lccc}
\hline & AA genotype & AK genotype & KK genotype \\
\hline Mean milk yield (litres per 305 days) & 5427 & 5598 & 5390 \\
Fat content (\%) & 3.93 & 4.05 & 4.12 \\
Protein content $(\%)$ & 3.37 & 3.41 & 3.21 \\
\hline
\end{tabular}

Table 4. Mean concentration of selected biochemical indices in blood serum of examined cows divided into the groups according to the DGAT-1 genotype (mean values \pm standard deviations)

\begin{tabular}{lccc}
\hline \multirow{2}{*}{ Index } & \multicolumn{3}{c}{ Genotype } \\
\cline { 2 - 4 } & AA & AK & KK \\
\hline Glucose (mmol/l) & $3.8 \pm 0.62$ & $3.6 \pm 0.30$ & $3.7 \pm 0.49$ \\
Total cholesterol (mmol/l) & $3.1 \pm 1.48$ & $4.0 \pm 1.65$ & $3.5 \pm 1.53$ \\
Total lipids (mmol/l) & $3.7 \pm 1.69$ & $3.9 \pm 1.61$ & $3.8 \pm 2.33$ \\
Triacylglycerides (mmol/l) & $0.16 \pm 0.117^{*}$ & $0.13 \pm 0.113^{*}$ & $0.25 \pm 0.078$ \\
Non-esterified fatty acids (mmol/l) & $0.5 \pm 0.41^{* *}$ & $0.3 \pm 0.15$ & $0.3 \pm 0.19$ \\
B-hydroxybutyrate (mmol/l) & $0.7 \pm 0.66$ & $0.7 \pm 0.65$ & $0.5 \pm 0.48$ \\
Lactate dehydrogenase (mmol/l) & $49.8 \pm 10.49^{* *}$ & $47.8 \pm 6.78^{* *}$ & $42.4 \pm 13.65$ \\
Total bilirubine (mmol/l) & $8.6 \pm 6.95^{* *}$ & $7.6 \pm 3.19^{* *}$ & $4.7 \pm 0.08$ \\
Total immunoglobulins (UZST) & $26 \pm 5.8$ & $27 \pm 4.6^{* *}$ & $30 \pm 0.5^{* *}$ \\
\hline
\end{tabular}

*values below the reference range used in the Clinic for Ruminants, University of Veterinary Medicine in Kosice, **values above the reference range used in the Clinic for Ruminants, University of Veterinary Medicine in Kosice

Mean serum concentrations of selected biochemical indices are described in Table 4. Tukey's test showed no significant differences $(P>0.05)$ between the groups. However, we noticed some variations within the groups considering the values outside the reference 
range. In our opinion, while $K$ allele should be responsible for milk fat yield, $A$ allele could play a role in increasing of total milk yield. The reason of altered indicators could have a connection to the higher milk production, and subsequent pronounced negative energy balance, and impaired liver functions due to the liver steatosis.

Genotype frequencies for given locus also differed according to breed, but also within the same breed. The study showed little differences among individual genotypes in relation to the given biochemical indices in blood serum. This may have been caused by low number of animals, mainly of $K K$ genotype involved in the study. Polymorphism in DGAT1 gene, as stated before, strongly influences the milk, fat and protein yield in dairy cows. On the other hand, it seems most likely that the effect of DGAT1 gene on biochemical indices, and thus health state of animals after parturition was only indirect via production/ reproduction traits. This effect was most probably the result of polygene network together with environmental factors playing a role in the formation of general performance of cattle.

\section{Discussion}

The occurrence of individual genotypes in various populations has been closely related to selection in different countries, concerning also the type of desired yield, and the origin of animals. According to the study of Gautier et al. (2007), AA genotype predominantly occurs in the bulls of Montbeliarde and Norman breeds, where presence of homozygotes for $K K$ genotype has not been detected. In Holstein cattle they noticed more even allele distribution, where $43 \%$ of individuals were heterozygouos $(A K)$, and $10 \%$ of animals proved to be $K K$ homozygotes. As stated by Berry et al. (2010), the frequency of the $K K$, $A K$, and $A A$ genotypes was $0.11,0.42$ and 0.47 , respectively, in Irish Holstein-Friesian cattle, which is consistent with the genotype frequencies for Holstein-Friesian populations in UK, Greece, France, and the Netherlands. The opposite state was recorded by Patel et al. (2009), who reported that in Indian Holstein bulls, $K K$ genotype frequency $(0.21)$ was higher than $A A(0.03)$ but lower than $A K$ genotype (0.76). The $K$ allele was present in more than $50 \%$ of Holstein bulls which could be possibly explained by selection of Indian Holstein cattle for higher milk fat content. High frequency of $A$ allele has recently been reported in Holstein cattle and its crossbreds by Lacorte et al. (2006). On the other hand, they have also reported absence of $A$ allele in Nellore and Guzerat cattle and less than $5 \%$ presence of $A$ allele in Gyr and Redsindhi cattle of Brazil. Komisarek et al. (2011) recorded similar genotype frequencies in their study in Jersey cows $(0.62,0.33$ and 0.05$)$ as we did in our population of animals, with the low frequency of $K K$ genotype presented. In another study in Polish Black-and-White bulls they detected frequencies of 0.38 and 0.62 for $K$ and $A$ alleles, respectively, with excess of $K A$ heterozygotes mainly at the expense of homozygotes $A A$ which according the authors may indicate the presence of overdominant selection (Komisarek and Michalak 2008).

Grisart et al. (2004) noted a significant effect of $K$ allele on the amount of triglycerides synthesized, with $K$ allele being more than $1.5 \times$ the amount synthesized with $A$ allele. Some unfavourable correlations between the DGAT1 - $A$ allele and total body energy content, BCS condition, blood glucose and NEFA concentrations in Holstein-Friesian cows were found by Oikonomou et al. (2009). On the contrary, Komisarek et al. (2011) stated that polymorphism of DGAT1 gene seems to have no influence on the functional traits in Jersey cows. However, they noted that homozygotes $A A$ were characterized by the highest breeding values of non-return rates, both in heifers and in cows. In contrast, for the age at first insemination and for calving-to-conception and calving-to-first service interval, $K K$ genotype seemed to be the most favourable (Komisarek and Michalak 2008). In general, this may have connection to the negative energy balance after calving that negatively influences reproduction properties (Leroy et al. 2006; Kaupe at el. 2007). 


\section{Acknowledgements}

This study was written during realization of the projects "LAGEZ No. 26220120051", "MARKERY No. 26220220033" supported by the Operational Programme Research and Development funded from the European Regional Development Fund as well as by VEGA Scientific Grant No. 1/0592/12 from the Ministry of Education and by Slovak Research and Development Agency under contract No. APVV-0475-10.

\section{References}

Berry DP, Howard D, O’Boyle P, Waters S, Kearney JF, McCabe M 2010: Associations between the K232A polymorphism in the diacylglycerol-O-transferase 1 (DGAT1) gene and performance in Irish Holstein-Friesian dairy cattle. Irish J Agric Food Res 49: 1-9

Boichard D, Grohs C, Bourgeois F, Cerqueira F, Faugeras R, Neau A, Rupp R, Amigues Y, Boscher MY, Leveziel $\mathrm{H}$ 2003: Detection of genes influencing economic traits in three French dairy cattle breeds. Genet Sel Evol 35 : 77-101

Gautier M, Capitan A, Fritz S, Eggen A, Boichard D, Druet T 2007: Characterization of the DGAT1 K232A and variable number of tandem repeat polymorphisms in French dairy cattle. J Dairy Sci 90: 2980-2988

Grisart B, Farnir F, Karim L, Cambisano N, Kim JJ, Kvasz A, Mni M, Simon P, Frere JM, Coppieters W, Georges M 2004: Genetic and functional confirmation of the causality of the DGAT1 K232A quantitative trait nucleotide in affecting milk yield and composition. Proc Natl Acad Sci 101: 2398-2403

Kaupe B, Brandt H, Prinzenberg EM, Erhardt G 2007: Joint analysis of the influence of CYP11B1 and DGAT1 genetic variation on milk production, somatic cell score, conformation, reproduction, and productive lifespan in German Holstein cattle. J Anim Sci 85: 11-21

Kaupe B, Winter A, Fries R, Erhardt G 2004: DGAT1 polymorphism in Bos indicus and Bos taurus cattle breeds. J Dairy Res 71: 182-187

Komisarek J, Michalak A, Walendowska A 2011: The effects of polymorphisms in DGAT1, GH and GHR genes on reproduction and production traits in Jersey cows. Anim Sci Pap Rep 29: 29-36

Lacorte GA, Machado MA, Martinez ML, Campos AL, Maciel RP, Verneque RS, Teodoro R L, Peixoto MGCD, Carvalho MRS, Fonseca CG 2006: DGAT1 K232A polymorphism in Brazilian cattle breeds. Genet Mol Res 5: 475-482

Leroy JL, Vanholder T, Opsomer G, Van Soom A, De Kruif A 2006: The in vitro development of bovine oocytes after maturation in glucose and beta-hydroxybutyrate concentrations associated with negative energy balance in dairy cows. Reprod Domest Anim 41: 119-123

Loor JJ, Dann HM, Janovick-Guretzky NA, Everts RE, Oliveira R, Green CA, Litherland NB, Rodriguez-Zas SL, Lewin HA, Drackley JK 2006: Plane of nutrition prepartum alters hepatic gene expression and function in dairy cows as assessed by longitudinal transcript and metabolic profiling. Physiol Genom 27: 29-41

Oikonomou G, Angelopoulou K, Arsenos G, Zygoyiannis D, Banos G 2008: The effects of polymorphisms in the DGAT1, leptin and growth hormone receptor gene loci on body energy, blood metabolic and reproductive traits of Holstein cows. Anim Genet 40: 10-17

Patel RK, Chauhan JB, Soni KJ, Singh KM 2009: Genotype and allele frequencies of DGAT1 gene in Indian Holstein bulls. Curr Trends Biotechnol Pharm 3: 386-389

Sordillo LM, Contreras GA, Aitken S 2009: Metabolic factors affecting the inflammatory response of periparturient dairy cows. Anim Health Res Rev 10: 53-63

Szatkowska I, Grzesiak W, Jedrzejczak M, Dybus A, Zaborski D, Jankowiak D 2011: An analysis of CYP19, $C Y P 21$ and ER genotypes in Polish Holstein-Friesian cows with regard to the selected reproductive traits. Acta Vet Brno 80: 65-71

Thaller G, Krämer W, Winter A, Kaupe B, Erhardt G, Fries R 2003: Effects of DGAT1 variants on milk production traits in German cattle breeds. J Anim Sci 81: 1911-1918

Winter A, Kramer W, Werner F A, Kollers S, Kata S, Durstewitz G, Buitkamp J, Womack J E, Thaller G, Fries R 2002: Association of a lysine-232/alanine polymorphism in a bovine gene encoding acyl-CoA:diacylglycerol acyltransferase (DGAT1) with variation at a quantitative trait locus for milk fat content. Proc Natl Acad Sci USA 99: 9300-9305 
Plate VII

Lešková L. et al.: Detection of ... pp. 265-267

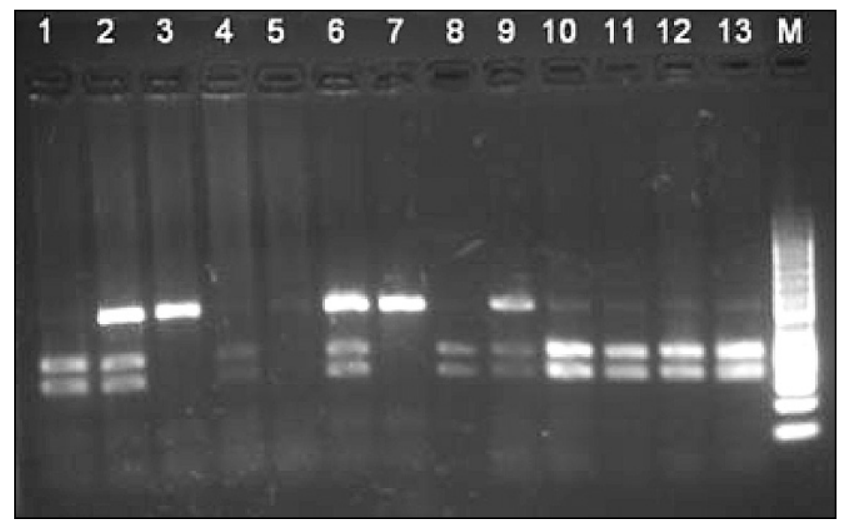

Fig. 1. Electrophoretogram of $C f r 1$ digested PCR product generated by amplification of genomic DNA using DGAT1 $K 232 A$ specific primers.

M - 50 bp DNA ladder, samples 1, 8, 10 - 13 with $A A$ genotype, samples 2, 6, 9 with $A K$ genotype, samples 3,7 with $K K$ genotype (uncut variant), samples in lines 4, 5 were too blurred to be sufficient for the analysis 